to planting ; the effects of the application of fertilizers on the vigour of the root systems; differences occur. ring in the root systems of the species studied; and the comparative ability of the root systems of these species to exploit the soil both in their natural state and when cultivated. An upland heath has been defined as "A Callunetum on shallow peat in which the roots of the vascular plants penetrate into the sub-peat layer". The peat is commonly two to four inches thick. Notes are given on the distribution of these heaths and the methods used, the findings, and the conclusions of an investigation into the root development of the principal conifers used extensively by the Forestry Commission in the north of England, such as Japanese larch, Scots pine, Sitka spruce, lodgepole pine and Corsican pine.

\section{Systematics Association: Meeting in Edinburgh}

A MeETine of the Systematics Association was held at the Royal Botanic Garden, Edinburgh, during September 16-17. The three sessions were devoted respectively to the criteria of species, genera and families. Each session had a single main paper followed by general discussion, the principal speakers being Prof. I. Manton (species), Prof. T. G. Tutin (genera) and Mr. E. J. H. Corner (families). The meeting took its lead from the very beautiful electron micrographs of minute structure in the flagellate Chrysochromulina shown by Prof. Manton, and the prime necessity for accurate and detailed factual knowledge was emphasized at all three discussions. Two other themes also recurred : first, the difficulty of incorporating new types of data into the classification unless such data cover the whole geographical and taxonomic range of the unit under study; secondly, the need for continued availability of the old categories in an aggregate sense, even when research has shown their subdivision to be necessary in critical work. The meeting terminated with a visit to the new establishment of the Scottish Society for Research in Plant Breeding.

Among those attending the meeting were students from a vacation course in practical taxonomy which had just been given in the University Department of Botany at Edinburgh, and Dr. P. H. Davis outlined the scope of this course during an informal soirée on the Friday evening. Following lectures on some important aspects of herbarium work, the students had been set to revise small groups of Mediterranean species. The course made full use of the excellent herbarium and library facilities at Edinburgh, and was intended to fill a gap which must often arise in botanical teaching elsewhere.

\section{Bibliographical Survey of Flexure Devices}

The British Scientific Instrument Research Association has started to publish a series of bibliographical surveys on instrument parts, and the first of this series is entitled "Flexure Devices", by P. J. Geary (pp. 44 ; from the Association at Chislehurst, Kent; $1955 ; 10 s .6 d$.$) . It is a booklet comprising an illus-$ trated technical introduction, digests of twenty-eight selected texts of major importance, an annotated list of one hundred and eleven references to texts of secondary importance, supplementary references and a name index. The period covered by the survey is from 1900 to the present. Periodical, book and report literature has been searched methodically, but not patent literature, although digests of some patent specifications have been included. No claim is made to complete coverage. Flexure devices take many forms, and for the purpose of the survey they havo been grouped under the six headings: flexure pivots, parallel movements, twin strip mechanisms, buckling strip devices, rolling suspensions and the sine spring. These are described in some detail in the technical introduction, and their advantages and limitations are mentioned. Reference is made to the general use of flexible strips in gauging instruments following their introduction in about 1916 by the Metrology Department (now Division) of the National Physical Laboratory, Teddington, and to the forthcoming useful review, "The Application of Spring Strips to Instrument Design," to be published in the series of "Notes on Applied Science" of the National Physical Laboratory. The sine spring, a resilient member of adjustable stiffness, has been developed and applied by the Ministry of Supply.

National Foundation for Scientific Research, Brussels: Annual Report

The twenty-seventh annual report of the National Foundation for Scientific Research, Brussels (pp. 227 ; from the Foundation), covers the year 1953-54 and records a fourth grant, of $1,671,000$ francs, to the Cornmission for Clinical Research. Of this, 350,000 franes went to the University of Ghent, 520,000 franes to the University of Liège, 345,000 francs to the University of Brussels, and 456,000 francs to the Catholic University of Louvain, chiefly for work on cortisone and the adrenocorticotropic hormone; lists of publications are appended to brief reports from each of these centres. Special grants made during the year include 200,000 francs for research on a scientific method of determining the mechanical characteristics of hydraulic cement; 250,000 franes for investigations on the physiology and pharmacology of the pulmonary circulation; and 750,000 francs for work on calculating machines in the university laboratories. Brief notes on the work on the utilization of radioisotopes at the Universities of Brussels, Ghent, Liège and Louvain, at the State Agronomic Institute at Gembloux, as well as in industry, are included. A further 2,000,000 francs was voted to the Interuniversity Microfilm Commission, and 100,000 franes for low-temperature research at the University of Louvain. Lists of recipients of grants for 1953-54 and of publications by recipients of grants during 1952-54 are appended.

\section{Queen Victoria Museum and Art Gallery, Launces-} ton, Tasmania : Annual Report

THE annual report for 1953-54 of the Queen Victoria Museum and Art Gallery, Launceston, Tasmania (pp. 7 ; from the Museum ; 1955), indicates progress in many directions. The vertebrate gallery has been reorganized, new displays have been completed in the new anthropological gallery, a new series of Tasmanian fossils has been placed on exhibition, the watercolour gallery has been re-hung, and photographic copies of certain paintings made available for art historians. The matter of public relations has been one for serious attention, and there is ample evidence in the report that the services provided by the Institution are appreciated by the community.

\section{Classified List of Egyptian Scientific Papers}

Is 1952 the National Research Council of Egypt started to compile and issue annual lists of research papers published in Egypt and by Egyptians abroad. The third volume has recently appeared (pp. 127; from the Council, Cairo) covering papers published in 